\title{
HAK DAN KEWAJIBAN MASYARAKAT INDONESIA TERHADAP PELAKSANAAN VAKSINASI COVID-19
}

\author{
Whindy Salsa Nabila \\ IIK STRADA INDONESIA \\ whindysalsanabila@gmail.com
}

\begin{abstract}
ABSTRAK
Pandemi Covid-19 mengakibatkan status kedaruratan di Indonesia. Melalui keputusan presiden Nomor 11 tahun 2020, Indonesia sudah mengumumkan status kedaruratan kesehatan. Berbagai upaya dilakukan dalam rangka mengatasi dampak pandemi Covid-19 salah satunya ialah upaya vaksinasi. Namun, di masyarakat timbul pro kontra terkait vaksinasi tadi. Sejumlah kalangan masyarakat menolak untuk divaksin. Oleh karena itu, artikel ini akan menjelaskan apakah vaksinasi adalah hak atau kewajiban bagi masyarakat dan apakah penolak vaksin bisa dikenakan sanksi pidana. Hasil penelitian menunjukkan bahwa vaksinasi yang pada mulanya adalah hak setiap orang, bisa sebagai suatu kewajiban mengingat situasi kedaruratan di Indonesia saat ini.
\end{abstract}

\section{Kata Kunci : Hak dan Kewajiban}

\section{LATAR BELAKANG}

Wabah corona virus disease 2019 atau disebut sebagai Covid-19 yang melanda global pada tahun 2020 mengakibatkan kedaruratan di berbagai negara, salah satunya merupakan Indonesia. Pandemi Covid-19 yang melanda seluruh negara pada dunia mengubah tatanan kehidupan manusia. Pada perkembangan penanganan Covid-19 diberbagai global, ada sejumlah penelitian dalam rangka pembuatan vaksin juga obat untuk mengatasi Covid-19. Khusus berkaitan dengan vaksin, ada sejumlah merek vaksin untuk Covid-19 yang telah dirancang, Indonesia memakai sejumlah merek vaksin dalam rangka penanganan Covid-19 di Indonesia.

Pemerintah melalui menteri kesehatan menyatakan bahwa telah mendistribusikan 1,2 juta takaran vaksin Covid-19 ke 34 provinsi di seluruh Indonesia per 7 januari 2021. Pemerintah melalui wakil menteri aturan dan hak asasi manusia memberikan bahwa vaksinasi Covid-19 artinya bagian dari kewajiban seluruh masyarakat negara untuk mewujudkan kesehatan masvarakat. Selain itu masyarakyat juga mempertanyakan efikasi serta efektivitas vaksin Covid-19 tersebut dengan dalih seperti tidak efektif, isu konspirasi, menyebabkan imbas samping termasuk aspek kehalalannva walaupun berkaitan menggunakan aspek kehalalannya telah dinyatakan suci serta halal oleh majelis ulama Indonesia. Bahkan ada daerah yang menyatakan bahwa masvarakat yang menolak 
vaksin Covid-19 akan dikenakan denda, sebagai contoh pada DKI jakarta, yang mana pada peraturan daerah provinsi daerah khusus lbukota jakarta Nomor 2 tahun 2020 penanggulangan Covid-19 DKi jakarta yang menyebutkan bahwa setiap orang yang dengan sengaja menolak dilakukan pengobatan dan /atau vaksinasi Covid-19 bisa dipidana dengan hukuman sebesar Rp5.00o.ooo.

Berdasarkan latar belakang di atas maka di artikel ini akan membahas mengenai:

Apakah vaksinasi Covid-19 adalah hak ataukah kewajiban bagi masyarakat, dan bagaimana pemidanaan terhadap penolak vaksin Covid-19 ditinjau dari norma aturan pada Indonesia?

\section{KASUS/MASALAH}

Di masyarakat, terjadi pro serta kontra terkait penggunaan vaksinasi di Indonesia, sejumlah pihak mempertanyakan apakah efikasi dan efektivitas dari vaksin Covid19? Dan apakah vaksinasi tersebut terjamin kehalalannya. Bahkan terdapat daerah yang menyatakan menolak melakukan vaksin Covid-19.

\section{TINJAUAN PUSTAKA}

Wabah corona virus disease 2019 atau disebut juga Covid-19 yang melanda global pada tahun 2020 mengakibatkan kedaruratan di berbagai negara, salah satunya Indonesia. Pandemi Covid-19 yang melanda seluruh negara di dunia mengubah tatanan kehidupan manusia. Umat manusia dipaksa mengikuti keadaan dengan norma baru. di Indonesia norma baru tersebut tercermin pada adanya 'pesan bunda' yang berisikan kewajiban 3M (menggunakan masker, menjaga jarak dan mencuci tangan menggunakan sabun) bagi warga dan 3T (testing, tracing, treatment) bagi pemerintah. Berkaitan dengan penanganan pandemi Covid-19 di Indonesia, pemerintah sudah mengambil langkah-langkah dalam rangka melindungi kesehatan warga negara. Mulai dari menetapkan status darurat kesehatan, melaksanakan kewajiban pemerintah dalam rangka melaksanakan 3T (testing, tracing, treatment), membangun rumah sakit darurat bahkan sampai melakukan pembatasan di berbagai daerah. 


\section{PEMBAHASAN}

\section{A. Vaksinasi Covid-19 menjadi Hak atau Kewajiban bagi Masyarakat}

Kesehatan adalah keadaan sehat, baik secara fisik, mental, spritual juga sosial vang memungkinkan setiap orang buat hidup produktif secara sosial serta ekonomis. Sebab itu kesehatan merupakąn dasar diakuinya derajat kemanusiaan. Tanpa kesehatan, seseorang menjadi tak sederajat secara kondisional. Tanpa kesehatan, seseorang tak akan mampu memperoleh hak-hak lainnya, sehingga kesehatan menjadi salah satu ukuran selain tingkat pendidikan dan ekonomi yang memilih mutu asal sumber daya manusia.

Hak atas kesehatan menjadi hak asasi manusia sudah diakui dan diatur pada berbagai instrumen internasional. Indonesia adalah negara yang menyampaikan pelindungan secara konstitusional terhadap hak asasi manusia. Pelindungan terhadap HAM tersebut dimasyarakatkan secara luas dalam rangka mempromosikan penghormatan pelindungan terhadap hak hak asasi manusia sebagai ciri yang penting suatu negara hukum yang demokratis.

Berkaitan dengan pelindungan konstitusional terhadap hak atas kesehatan mental tercermin dalam pasal $28 \mathrm{~h}$ ayat undang undang dasar negara republik Indonesia tahun 1945 yang menyatakan bahwa "setiap orang berhak hidup sejahtera lahir dan batin, bertempat tinggal serta menerima lingkungan hidup yang baik dan sehat serta berhak memperoleh pelayanan kesehatan"

Bahkan, lebih lanjut disebutkan juga mengenai kewajiban negara terkait hal tadi dalam pasal 34 ayat yang menyatakan bahwa "negara bertanggung jawab atas penyediaan fasilitas pelayanan kesehatan dan fasilitas pelayanan awam yang layak. Hal ini menunjukkan bahwa hak atas kesehatan termasuk di dalamnya kesehatan mental dilindungi secara konstitusional. Disebutkannya konsep perihal hak asasi yang berkaitan dengan kesehatan tadi, maka negara mempunyai kewajiban untuk memenuhi hak tersebut.

Berkaitan dengan penanganan pandemi Covid-19 di Indonesia, pemerintah sudah mengambil langkah-langkah dalam rangka melindungi kesehatan warga negara. Mulai dari menetapkan status darurat kesehatan melalui keputusan presiden Nomor 11 tahun 2020 tentang penetapan kedaruratan kesehatan warga corona 
virus disease 2019, melaksanakan kewajiban pemerintah dalam rangka melaksanakan 3T (testing, tracing, treatment), membangun rumah sakit darurat bahkan sampai melakukan pembatasan pada berbagai daerah sebagaimana yang tertuang dalam peraturan pemerintah Nomor 21 tahun 2020 tentang pembatasan sosial berskala besar dalam rangka percepatan penanganan corona virus diseose 2019.

\section{B. Penolak Vaksin Diberikan Hukuman Pidana Atau Tidak}

Penolak vaksin diberikan hukuman pidana atau tidak di penjeiasan sebelumnya disebutkan bahwa vaksinasi ialah salah satu upaya untuk menuju situasi kenormalan kembali seperti sebelum adanya pandemi. Untuk menjawab pertanyaan tersebut, maka harus terlebih dahulu di jelaskan mengenai hukum pidana kaitannya menggunakan hukum administrasi, Ridvan Hr secara singkat menyebutkan bahwa hukum administrasi artinya kaitan menggunakan aturan untuk mengatur pemerintah atau penyelenggaraan pemerintahan. jum Anggriani mengungkapkan bahwa hukum administrasi negara artinya segala aturan aturan yang berisikan peraturan yang menjadi panduan dari aparatur negara dalam menjalankan tugasnya sebagai penyelenggara pemerintah. Sedangkan menurut black's low dictionary, administrotive iaw adalah that branch of public iaw which deals with the various organs of the sovereign power considered as in motion, and prescribes in detail the manner of their activity, being concerned with such topics as the collection of the revenue, the tregulation of the military and naval forces, citizenshipand naturalization, sanitary measures, poor laws, police, the public safety and morals.

Hukum pidana kaitannya dengan aturan administrasi artinya dalam rangka menegakkan hukum administrasi itu sendiri. Jika dihubungkan lebih jauh kaitannya bernegara, maka adanya hukum pidana administrasi tersebut merupakan dalam rangka untuk melindungi masyarakat itu sendiri. Secara umum hukum pidana Indonesia pada dasarnya menganut mekanisme ultimum remedium yang dapat diartikan bahwa pengaturan sanksi pidana diposisikan menjadi sanksi terakhir. Pada suatu Undang-Undang hendaknya hukuman yang diatur pertama kali adalah sanksi administratif atau hukuman 
perdata, sedangkan untuk sanksi pidana diatur atau diletakkan menjadi bentuk pengenaan hukuman terakhir. Bahkan setara spesifik terkait vaksinasi, wakil menteri hukum serta hak asasi manusia republik Indonesiai prof. Edward omar sharif hiariej menyampaikan bahwa Undang-Undang wabah penyakit menular maupun undang undang karantina kesehatan adalah hukum administrasi yang diberi sanksi pidana sebagai akibatnya disebut juga 'hukum pidana administrasi. Sebagai akibatnya dalam konteks ini sanksi pidana bersifat ultimum remedium ialah sarana yang paling akhir digunakan untuk menegakkan hukum pidana, apabila pranata penegakan hukum lainnya tidak lagi berfungsi. Pada negara demokratis, penggunaan paksaan hendaknya digunakan seminimal mungkin serta sedapat-dapatnya menggunakan metode persuasif pada praktiknya terdahulu, penggunaan paksaan ketat selain memerlukan organisasi yang ketat, juga memerlukan biaya yang tinggi. Berdasarkan konsep di atas, maka kebijakan kewajiban vaksinasi kepada masyarakat dapat diarahkan sebagai berikut:

1. Intinya, masyarakat memang diwajibkan untuk melakukan vaksinasi. Namun kewajiban tadi jangan diarahkan terhadap satu merek atau produk tertentu. Sebagaimana yang disebutkan di penjelasan sebelumnya bahwa pemerintah Indonesia hekerja sama untuk melakukan pembelian terhadap vaksin sinovac, novavax, covax/gavi, astrazeneca dan pfizer. Seiain itu, Indonesia saat ini juga tengah mengembangkan produk vaksin buatan dalam negeri, yakni vaksin merah putih sehingga dalam hal ini masyatakat dapat memilih merek vaksin mana yang mereka pergunakan sepanjang vaksin tadi mendapatkan persetujuan dari BPOM.

2. Setiap penerapan kebijakan sebaiknya didahului dengan metode persuasif seperti sosialisasi serta sejenisnya. Berkaitan dengan proses vaksinasi, sebelum hal tersebut dilakukan, sebaiknya negara menggunakan metode persuasif menengajak masyarakyat melalui tokoh-tokoh masyarakat baik secara lokal maupun nasional untuk turut mensukseskan program vaksinasi yang direncanakan oleh pemerintah.

3. Hukuman pidana hanya dipergunakan sebagai cara terakhir ketika pranata pranata lainnva tidak berfungsi seperti telah diadakan sosialisasi menggunakan metode persuasif, penyuluhan bahkan hingga sanksi administratif sudah 
dilaksanakan, sedangkan situasi kondisi di Indonesia semakin memrutuk akibat Covid-19 sebagai akibatnya untuk menyelamatkan Indonesia beserta segenap unsurnya dari kondisi memburuk tadi, barulah sanksi pidana bisa diberlakukan.

4. pemerintah pusat juga wajib mengawasi pelaksanaan sanksi pada tingkat wilayah sebagaimana yang sudah pada sebutkan sebelumnya, bahwa salah satu daerah yang telah mencantumkan hukuman terkait pelaksanaan vaksin pada peraturan wilayahnya, yang mana pada peraturan daerah provinsi daerah khusus ibu kota lakarta nomar 2 tahun 2020 tentang penangulangan Covid-19 DKI lakarta yang menyebutkan bahwa setiap orang dengan sengaja menolak untuk dilakukan pengobatan dan vaksinasi dapat dipidana dengan denda paling banyak sebesar Rp.5.000.000.padahal dalam penanggulangan wabah penyakit, sanksi pidana maksimal Rp.1.000.000. Lantas bagaimana peraturan daerah yang secara struktural berada pada bawah UU bisa mengeluarka denda sampai Rp.5.000.000. Bila pemerintah daerah DKI UU ingin memberikan hukuman, maksimal harus sebanyak hukuman pidana UU penanggulangan wabah penyakit yaitu Rp 1.000 .000 atau di bawahnya.

\section{KESIMPULAN}

Berdasarkan pembahasan di atas, maka bisa disimpulkan bahwa vaksinasi dalam rangka penanganan Covid-19 merupakan suatu hak sekaligus kewajiban dari masyarakat Indonesia. Memang, ada hak seorang buat menentukan pelayanan kesehatan baginya tetapi, Bila dipandang pada konteks virus Covid-19 yang berskala pandemi, dan merujuk di poin ke 2 bahwa seseorang yang tidak divaksin justru dapat berpotensi sebagai virus carrier bagi orang iain, maka hak tadi bisa dikurangi dalam rangka untuk mencapai tujuan negara yakni melindungi segenap bangsa Indonesia serta seluruh tumpah darah Indonesia dalam hal itu melindungi diri dari virus Covid-19, dan pula termasuk melindungi hak asasi seorang itu sendiri dalam rangka memperoleh hak untuk hidup secara sehet. Oleh sebab itu, vaksinasi yang pada mulanya ialah suatu hak bagi seorang bisa berubah sebagai suatu kewajiban mengingat negara pada keadaan darurat serta selanjutnya 
artinya berkaitan dengan kewajiban asasi manusia untuk menghargai hak asasi orang Iain, dalam hal ini adalah hak atas kesehatan orang Iain.

Adapun terkait sanksi pidana dalam pemberlakuan kewajiban vaksinasi, sebaiknya tetap menjadi suatu sarana terakhir (ultimum remedium) apabila pranata pranata iain nya tidak berfungsi. Namun, melihat situasi syarat di Indonesia semakin memburuk akibat Covid-19, sehingga dimungkinkan untuk menyelematkan Indonesia bersama segenap unsurnya dari kondisi yang kian memburuk tersebut, dengan penerapan hukuman pidana dapat diberlakukan.

\section{DAFTAR PUSTAKA}

Gandryani, F., \& Hadi, F. (2021). PELAKSANAAN VAKSINASI COVID-19 DI INDONESIA: HAK ATAU KEWAJIBAN WARGA NEGARA. Jurnal Rechts Vinding: Media Pembinaan Hukum Nasional, 10(1), 23.

Afandi\} Dedi., "Hak Atas Kesehatan Dalam PerspektifHAM." Jurnal iImu Kedokteran Jilid 2 Nomor 1. ISSN 198-662X (Maret 2008).

Handayani, Rina Tri. et.al. "Pandemi Covid-19" Respon Imun Tubuh, Dan Herd Immunity," Jurnal llmiah Permas, Sekolah Tinggi limu Kesehatan Kendal, Volume 10 No-3 (2020). 